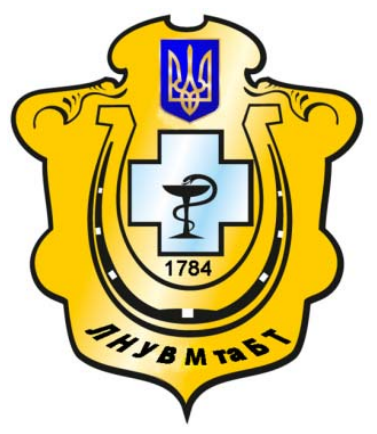

Науковий вісник Львівського національного університету ветеринарної медицини та біотехнологій імені С.3. Гжицького

Scientific Messenger of Lviv National University of Veterinary Medicine and Biotechnologies named after S.Z. Gzhytskyj

doi:10.15421/nvlvet6820

ISSN 2413-5550 print

ISSN 2518-1327 online

$\underline{\text { http://nvlvet.com.ua/ }}$

УДК 637.354.8:577.1

\title{
Дослідження структурно-механічних показників бринзи за часткової заміни кухонної солі хлоридом калію
}

\author{
I.В. Скульська, О.Й. Цісарик \\ inna_skulska@ukr.net, tsisaryk_o@yahoo.com
}

Львівський національний університет ветеринарної медицини та біотехнологій імені С.3. Гжицького, вул. Пекарська, 50, м. Львів, 79010, Україна

У статті проаналізовано результати досліджень щодо впливу часткової заміни хлориду натрію хлоридом калію у кількості 20 і 30\% та використання бактеріального препарату прямого внесення - Fresh-Q (Chr.Hапsеn, Данія), що пригнічуе розвиток дріжджів і плісені на органолептичні та структурно-механічні показники бринзи з овечого молока. Встановлено, шо часткова заміна солі позитивно вплинула на формування органолептичних характеристик - смаку, запаху $і$ консистениії. Щодо використання бактеріального препарату Fresh-Q, то спостерігається формування вираженішого вершкового присмаку у дослідних зразках бринзи. Консистенція усіх зразків бринзи є однорідною, злегка ламкою, проте не крихкою, тобто такою, щь відповідає вимогам діючої нормативної документації на ией вид сиру. Результати підтверджсуються відповідною кількістю балів. Досліджено також структурно-механічні показники бринзи: твердість, жуйність, гумуватість, когезивність, пружність. Доведено доиільність використання бактеріального препарату Fresh-Q та частковоі заміни хлориду натрію хлоридом калію для покращення таких показників як жуйність, когезивність і пружність та, у свою чергу, зниження показників гумуватості та твердості у виготовленій бринзі. Найкращими результатами відзначаються зразки із 20\% заміною хлоридом калію та використанням Fresh-Q.

Ключові слова: бринза, хлорид натрію, хлорид калію, бактеріальний препарат, ферментний препарат, твердість, пружність, когезивність, гумуватість, жуйність.

\section{Исследование структурно-механических показателей брынзы при частичной замене поваренной соли хлоридом калия}

\author{
И.В. Скульская, О.И. Цисарык \\ inna_skulska@ukr.net, tsisaryk_o@yahoo.com
}

Львовский национальный университет ветеринарной медицины и биотехнологий имени С.3. Гжицкого, ул. Пекарская, 50, г. Львов, 79010, Украина

В статье проанализированы результаты исследований влияния частичной замены хлорида натрия хлоридом калия в количестве 20 и 30\% и использование бактериального препарата прямого внесения Fresh-Q (Chr.Hansen, Дания), который подавляет развитие дрожжей и плесени на органолептические и структурно-механические показатели брынзы из овечьего молока. Установлено, что частичная замена соли положительно повлияла на формирование органолептических характеристик вкуса, запаха и консистенции. Что касается использования бактериального препарата Fresh-Q, то наблюдается формирование выраженного сливочного привкуса в опытных образиах брынзы. Консистенция всех образиов брынзы является однородной, слегка ломкой, однако не хрупкой, то есть, соответствующей требованиям действующей нормативной документации на данный вид сыра. Результаты подтверждаются соответствующим количеством баллов. Исследовано также структурно-механические показатели брынзы: твердость, жуйность, резинистоть, когезивность, упругость. Доказана иелесообразность использования бактериального препарата Fresh-Q и частичной замены хлорида натрия хлоридом калия для улучшения таких показателей как жуйность, когезивность и упругость и, в свою очередь, снижение

\section{Citation:}

Skulska, I., Tsisaryk, O. (2016). Investigation of structural and mechanical parameters for brynza under the partially replace sodium chloride on potassium chloride. Scientific Messenger LNUVMBT named after S.Z. Gzhytskyj, 18, 2(68), 99-102. 
показателей резинистости и твердости в изготовленной брынзе. Лучшими результатами отмечаются образиы с 20\% заменой хлоридом калия и использованием Fresh-Q.

Ключевые слова: брынза, хлорид натрия, хлорид калия, бактериальный препарат, ферментный препарат, твердость, упругость, когезивность, резинистость, жуйность.

\title{
Investigation of structural and mechanical parameters for brynza under the partially replace sodium chloride on potassium chloride
}

\author{
I. Skulska, O. Tsisaryk \\ inna_skulska@ukr.net, tsisaryk_o@yahoo.com \\ Lviv National University of Veterinary Medicine and Biotechnologies named after S.Z. Gzhytskyi, \\ Pekarska Str., 50, Lviv, 79010, Ukraine
}

\begin{abstract}
The article analyzes the results of studies on the impact of partial replacement of sodium chloride on potassium chloride in an amount of 20 to 30\% and the use of starter Fresh-Q (Chr.Hansen, Denmark), which inhibits the growth of yeast and mold on the organoleptic and structural and mechanical properties of cheese from sheep's milk. As used bacterial culture direct introduction RSF-742 (Chr.Hansen, Denmark) containing composed such strains of lactic acid bacteria: Lactococcus lactis subsp. sremoris, Lactococcus lactis subsp. lactis, Streptococcus thermophilus, Lactobacillus helveticus. As used enzyme preparation CHY-MAX production company Chr.Hansen. Established that the partial replacement of salt a positive impact on the formation of organoleptic characteristics of taste, smell and consistency. Regarding the use of starter Fresh-Q, then there is a more pronounced butter flavor formation in the experimental samples of cheese. The consistency of all samples of cheese is smooth, slightly brittle but not brittle, ie one that meets current regulatory documentation for this type of cheese. The results confirmed the corresponding number of points. Also investigated the structural and mechanical properties of cheese, hardness, masticaticity, rubberity, cohesity, elasticity. The expediency of using starter Fresh-Q and partial replacement of sodium chloride on potassium chloride to improve indicators such as chewing, adhesion and elasticity and, in turn, decrease in hardness, rubberity and made cheese. The best results are marked samples with $20 \%$ potassium chloride and replacing and the use of Fresh-Q.
\end{abstract}

Key words: brine cheese, sodium chloride, potassium chloride, starter, enzyme, hardness, elasticity.

\section{Вступ}

В останні десятиріччя в Україні та світі спостерігається підвищення рівня споживання розсольних сирів 3 овечого молока, оскільки добре відома їх висока харчова та біологічна цінність. Однак розсольні сири відзначаються високим вмістом солі, що може негативно відображатись на здоров'ї споживачів, особливо людей похилого віку. Вітчизняними та зарубіжними фахівцями в області технології сирів ведуться роботи зі створення традиційних молочних продуктів зі зниженим вмістом солі. Для унеможливлення випадків погіршення якості бринзи, через знижений вміст солі ми пропонуємо ії частково замінити хлоридом калію у кількості 20 та $30 \%$. Така заміна кухонної солі хлоридом калію на сьогодні є актуальною у сироробстві. Вивченням цього питання при виробництві твердих сирів займалися вчені Австралії та США (Kulyev, 1972; Samedov, 1985; Horbatova, 1993; Kravtsiv et al., 2010), однак у галузі розсольних сирів такі дослідження не проводились.

На формування якісних показників сиру впливають різні чинники: хімічний склад і властивості молока, тривалість обробки згустку, розмір сирного зерна, швидкість і рівень кислотоутворення, склад і активність заквасок, кількість хлористого кальцію і кухонної солі, режими визрівання сиру, рівень $\mathrm{pH}$ і вміст вологи. Від цих показників залежить перебіг процесів, які обумовлюють властивості готового продукту (Bencini and Pulina, 1997; Turyns'kyj et al., 2000; Ayyash et al., 2012). Відповідно, заміна частини хлориду натрію хлоридом калію може призвести до змін у перебігу процесів під час виготовлення бринзи та відповідно у формуванні ії властивостей.
Матеріал та методи досліджень

Для виготовлення бринзи було використано овече молоко, що відповідає вимогам Стандарту (TU 10.16 USSR 71-89). Як молокозсідальний фермент використали ферментний препарат СНY-MAX виробництва фірми Chr.Hansen (Данія). CHY-MAX забезпечує високий вихід продукції з малою ймовірністю розвитку присмаку. Як заквашувальну культуру використано препарат прямого внесення RSF-742 (Chr.Hansen, Данія), що містить у своєму складі такі штами молочнокислих бактерій: Lactococcus lactis subsp. cremoris, Lactococcus lactis subsp. lactis, Streptococcus thermophilus, Lactobacillus helveticus.

Для забезпечення довготривалого зберігання виготовленого сиру ми використовували бактеріальний препарат Fresh-Q, який інгібує розвиток дріжджів i плісені у ферментованих молочних продуктах. Цей препарат є композицією культур традиційних молочнокислих бактерій, до складу якої входить Lactobacillus rhamnosus.

Виготовлено 6 зразків бринзи із триразовим повторенням. Умовні позначення зразків бринзи: К контрольний зразок із використанням хлориду натрію; Д1 - бринза, що виготовлена 3 20\% заміною хлориду натрію хлоридом калію; Д2 - бринза, що виготовлена з $30 \%$ заміною хлориду натрію хлоридом калію; KF - бринза, що виготовлена із використанням хлориду натрію та бактеріальним препаратом Fresh$\mathrm{Q}$; ДF1 - бринза, що виготовлена з 20\% заміною хлориду натрію хлоридом калію та використанням FreshQ; ДF2 - бринза, що виготовлена з 30\% заміною хлориду натрію хлоридом калію та використанням FreshQ. 
Сиропридатність молока визначали за сичужнобродильною та бродильною пробами за ГОСТ 922584; масову частку жиру, масову частку білку, густину молока, СЗМ3 визначали на апараті «Ekomilk» Butleh 2000 Ltd.; активну кислотність - потенціометричним методом за допомогою $\mathrm{pH}-$ метра марки АРН9; титровану кислотність - титрометрично (у градусах Тернера) згідно ГОСТ 3624-67; органолептичну оцінку сирів проводили згідно відповідної нормативної документації (ГОСТ 7616-85). Зразки сиру для досліджень структурно-механічних показників було відібрано за допомогою щупа діаметром 10 мм шляхом двократного занурення у брусок сиру на глибину 20 мм та його прокручування. Фаза релаксації тривала 30 с. Дослідження структурно-механічних показників здійснено за допомогою апарату Zwick/Roel Z010. Отримані результати були реєстровані та аналізовані за допомогою програми Texture Expert version 1.22. Було визначено такі показники: твердість, жуйність, гумуватість, когезивність, пружність.

\section{Результати та їх обговорення}

У таблиці 1 приведено дані про фізико-хімічні властивості овечого молока - сировини для виготовлення бринзи, вони відповідають вимогам діючої нормативної документації (ТУ 10.16 УССР $71-89$. Молоко овече. Вимоги при закупівлі), крім того було досліджено молоко на сиропридатність - воно визнане придатним для виробництва сиру.

\section{Таблиия 1}

Фізико-хімічні показники, хімічний склад та властивості овечого молока

\begin{tabular}{|c|c|c|c|c|c|c|c|}
\hline $\begin{array}{c}\text { Сиро- } \\
\text { вина }\end{array}$ & $\begin{array}{c}\text { М. ч. білка, } \\
\%\end{array}$ & $\begin{array}{c}\text { М. ч. } \\
\text { жиру, \% }\end{array}$ & $\begin{array}{c}\text { М. ч. лакто- } \\
\text { зи, \% }\end{array}$ & $\begin{array}{c}\text { М. ч. сухих } \\
\text { речовин, \% }\end{array}$ & $\begin{array}{c}\text { Густи-на, } \\
\text { кг/м }{ }^{3}\end{array}$ & $\begin{array}{c}\text { Активна кислот- } \\
\text { ність, од. } \mathrm{pH}\end{array}$ & $\begin{array}{c}\text { Титрована } \\
\text { кислотність, }{ }^{\circ} \mathrm{T}\end{array}$ \\
\hline $\begin{array}{c}\text { Овече } \\
\text { моло-ко }\end{array}$ & 5,10 & 5,70 & 4,63 & 17 & 1035,2 & 6,38 & 24 \\
\hline
\end{tabular}

Доведено позитивний ефект часткової заміни солі на органолептичні показники бринзи, зокрема консистенцію та зовнішній вигляд (табл. 2). Консистенцію оцінювали при температурі близько $20^{\circ} \mathrm{C}$, що пов'язано 3 властивостями молочного жиру, який може підвищувати щільність і пластичність сиру. Слід виокремити виражений вершковий смак зразків бринзи, які виготовляли з використанням бактеріального препарату Fresh-Q. В цілому, бринза відповідає вимогам Стандарту і за результатами бальної оцінки відноситься до сиру високої якості (табл. 3).

За показниками бальної оцінки, найбільшу кількість балів отримали зразки, виготовлені з 20 і 30\% заміною солі і використанням Fresh-Q.
Із приведених експериментальних даних (рис. 1) видно, що структурно-механічні показники в процесі дозрівання бринзи, котра виготовлена з 20 та 30\% заміною хлориду натрію хлоридом калію, зазнають змін. Мабуть, найважливішим структурномеханічним показником сиру є твердість, оскільки саме вона вказує на правильність формування сирного пласта та належне соління, тобто про перебіг таких фізичних явищ як осмотичне перенесення вологи $\mathrm{i}$ солі. Як відомо, до кінця визрівання твердість повинна знижуватися, а показники пластичності - зростати, що зумовлено розпадом білків.

Органолептичні показники бринзи з овечого молока за часткової заміни хлориду натрію хлоридом калію

\begin{tabular}{|c|c|c|c|c|c|}
\hline Зразок & Смак і запах & Консистенція & Рисунок & Колір & Зовнішній вигляд \\
\hline $\mathrm{K}$ & $\begin{array}{l}\text { Чистий кисломолочний, } \\
\text { в міру солоний, без } \\
\text { сторонніх присмаків та } \\
\text { запахів }\end{array}$ & $\begin{array}{l}\text { Однорідна, } \\
\text { ламка, але не } \\
\text { крихка }\end{array}$ & $\begin{array}{l}3 \text { поодинокими } \\
\text { вічками непра- } \\
\text { вильної форми }\end{array}$ & $\begin{array}{l}\text { Слабо-жовтий, } \\
\text { однорідний } \\
\text { всією масою }\end{array}$ & $\begin{array}{l}\text { Поверхня чиста, з відбит- } \\
\text { ками серп’янки. Кірка } \\
\text { відсутня. Незначна дефо- } \\
\text { рмація головки }\end{array}$ \\
\hline Д1 & $\begin{array}{l}\text { Чистий кисломолочний, } \\
\text { в міру солоний, без } \\
\text { сторонніх присмаків та } \\
\text { запахів. }\end{array}$ & $\begin{array}{l}\text { Однорідна, } \\
\text { ламка, але не } \\
\text { крихка }\end{array}$ & $\begin{array}{l}3 \text { поодинокими } \\
\text { вічками непра- } \\
\text { вильної форми }\end{array}$ & $\begin{array}{l}\text { Слабо-жовтий, } \\
\text { однорідний } \\
\text { всією масою }\end{array}$ & $\begin{array}{l}\text { Поверхня чиста, з відбит- } \\
\text { ками серп’янки. Кірка } \\
\text { відсутня. Незначна дефо- } \\
\text { рмація головки }\end{array}$ \\
\hline Д2 & $\begin{array}{l}\text { Чистий кисломолочний, } \\
\text { в міру солоний, без } \\
\text { сторонніх присмаків та } \\
\text { запахів. }\end{array}$ & $\begin{array}{l}\text { Однорідна, } \\
\text { ламка, але не } \\
\text { крихка }\end{array}$ & $\begin{array}{l}3 \text { поодинокими } \\
\text { вічками непра- } \\
\text { вильної форми }\end{array}$ & $\begin{array}{l}\text { Слабо-жовтий, } \\
\text { однорідний } \quad \text { за } \\
\text { всією масою }\end{array}$ & $\begin{array}{l}\text { Поверхня чиста, з відбит- } \\
\text { ками серп'янки. Кірка } \\
\text { відсутня. Незначна дефо- } \\
\text { рмація головки }\end{array}$ \\
\hline KF & $\begin{array}{l}\text { Чистий кисломолочний, } \\
\text { вершковий, в міру } \\
\text { солоний, без сторонніх } \\
\text { присмаків та запахів. }\end{array}$ & $\begin{array}{l}\text { Однорідна, } \\
\text { ламка, але не } \\
\text { крихка }\end{array}$ & $\begin{array}{l}3 \text { поодинокими } \\
\text { вічками непра- } \\
\text { вильної форми }\end{array}$ & $\begin{array}{l}\text { Слабо-жовтий, } \\
\text { однорідний } \\
\text { всією масою }\end{array}$ & $\begin{array}{l}\text { Поверхня чиста, з відбит- } \\
\text { ками серветки. Кірка } \\
\text { відсутня. Незначна дефо- } \\
\text { рмація головки }\end{array}$ \\
\hline ДF1 & $\begin{array}{l}\text { Чистий кисломолочний, } \\
\text { вершковий, в міру } \\
\text { солоний, без сторонніх } \\
\text { присмаків та запахів. }\end{array}$ & $\begin{array}{l}\text { Однорідна, } \\
\text { ламка, але не } \\
\text { крихка }\end{array}$ & $\begin{array}{l}3 \text { поодинокими } \\
\text { вічками непра- } \\
\text { вильної форми }\end{array}$ & $\begin{array}{l}\text { Слабо-жовтий, } \\
\text { однорідний } \\
\text { всією масою }\end{array}$ & $\begin{array}{l}\text { Поверхня чиста, з відбит- } \\
\text { ками серветки . Кірка } \\
\text { відсутня. Незначна дефо- } \\
\text { рмація головки }\end{array}$ \\
\hline ДF2 & $\begin{array}{l}\text { Чистий кисломолочний, } \\
\text { вершковий, в міру } \\
\text { солоний, без сторонніх } \\
\text { присмаків та запахів. }\end{array}$ & $\begin{array}{l}\text { Однорідна, } \\
\text { ламка, але не } \\
\text { крихка }\end{array}$ & $\begin{array}{l}3 \text { поодинокими } \\
\text { вічками непра- } \\
\text { вильної форми }\end{array}$ & $\begin{array}{l}\text { Слабо-жовтий, } \\
\text { однорідний } \\
\text { всією масою }\end{array}$ & $\begin{array}{l}\text { Поверхня чиста, з відбит- } \\
\text { ками серветки . Кірка } \\
\text { відсутня. Незначна дефо- } \\
\text { рмація головки }\end{array}$ \\
\hline
\end{tabular}


Бальна оцінка бринзи $з$ овечого молока

\begin{tabular}{|l|c|c|c|c|c|c|c|}
\hline \multicolumn{1}{|c|}{ Показник } & Максимальна кіль- & \multicolumn{5}{|c|}{ Зразки бринзи } \\
\cline { 3 - 8 } & кість балів & K & Д1 & Д2 & КF & ДF1 & ДF2 \\
\hline Смак і запах & 45 & 43 & 43 & 43 & 43 & 43 & 42 \\
\hline Консистенція & 25 & 22 & 22 & 23 & 24 & 24 \\
\hline Рисунок & 10 & 8 & 8 & 8 & 9 & 8 & 9 \\
\hline Колір сирного тіста & 5 & 5 & 5 & 5 & 5 & 5 & 5 \\
\hline Зовнішній вигляд & 10 & 7 & 7 & 8 & 8 & 8 & 9 \\
\hline Сума балів & 95 & 85 & 85 & 87 & 89 & 88 & 88 \\
\hline
\end{tabular}

Найвищим показником твердості характеризувався контрольний зразок та зразок KF з використанням Fresh-Q.

Встановлено, що існує деяка розбіжність між показниками когезивності продукту. Найвищим показником когезивності характеризується зразок Д1 (0,36 H/Mм), найменшим - KF (0,10 H/Mм).

Показовим $є$ те, що відбулось різке зниження показників гумуватості у досліджуваних зразках овечої бринзи $з$ використанням Fresh-Q =0,92 H/мм у KF проти 2,04 Н/мм у К, подібна тенденція зареєстрована i у зразках із заміною солі: $0,65 \mathrm{H} / \mathrm{Mм} \mathrm{у} \mathrm{ДF2} \mathrm{проти}$ 2,04 Н/мм у контролі. До того ж, 20\% заміна хлориду натрію та використання Fresh-Q здійснює позитивний ефект щодо зниження показників гумуватості для зразка ДF1, який становив 0,54 H/Mм, порівняно зі зразком Д $1-0,73 \mathrm{H} / \mathrm{Mм}$.

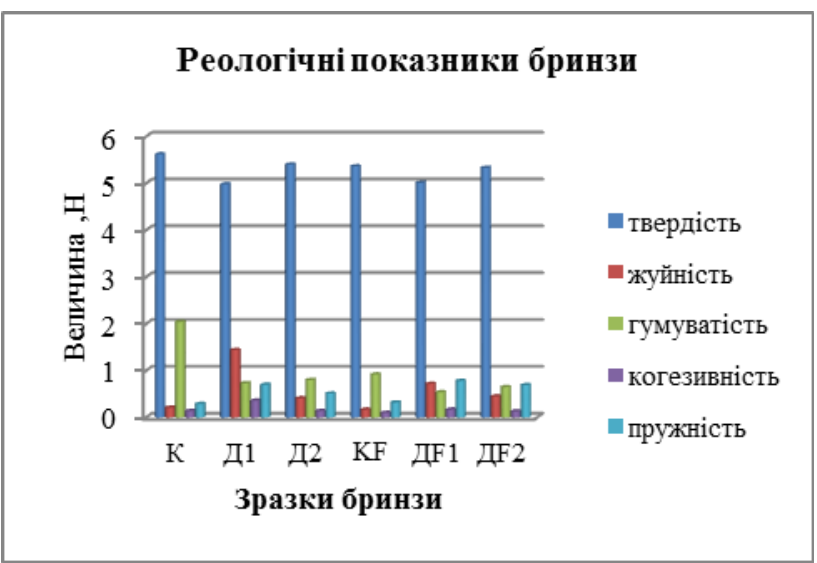

Рис. 1. Реологічні показники овечої бринзи з частковою заміною кухонної солі хлоридом калію

\section{Висновки}

Найбільша величина жуйності зареєстрована для зразка Д1, вона становила $(1,44$ Н/мм), найменша для зразка $\mathrm{KF}$.

Пружність досліджуваних зразків бринзи була найвищою у ДF1, а зразки Д1 та ДF2 характеризувалися практично однаковими показниками.
Виготовлена бринза з частковою заміною хлориду натрію за органолептичними показниками відповідає вимогам Стандарту. Доведено позитивний вплив часткової заміни кухонної солі хлоридом калію у кількості 20 та 30 \% та використання бактеріального препаpaтy Fresh-Q. Найкращими показниками характеризується зразок з 20 \% заміною хлориду натрію хлоридом калію. Завдяки використанню препарату Fresh-Q знижується твердість і гумуватість у зразках сиру, а зростає жуйність, когезивність та пружність.

\section{Бібліографічні посилання}

Kravtsiv, R.J., Tsisaryk, O.J., Paraniak, R.P. (2010). Biokhimiia moloka: L'viv (in Ukrainian).

Horbatova, K.K. (1993). Khymyia y fyzyka moloka M.: Kolos (in Russian).

Kulyev, N.D. (1972). Sostav y svojstva moloka korov, bujvolyts, ovets y puty eho ratsyonal'noho yspol'zovanyia pry proyzvodstve brynzy: avtoref. dys. ... kand. tekhn. nauk : 05.18.04. Moskva (in Russian).

Samedov, M.M. (1985). Khymycheskyj sostav y tekhnolohycheskye svojstva korov'eho, ovech'eho y bujvolynoho moloka y smesej eho pry proyzvodstve brynzy: avtoref. dys. ... kand. s.-h. nauk: 06.02.04 i 05.18.04; UzNYYZh SAO VASKhNYL. Tashkent (in Russian).

Turyns'kyj, V.M. Horlova, O.D., Tymofiiev, E.H. (2000). Tekhnolohiia vyrobnytstva ovechykh syriv $\mathrm{v}$ kolektyvnykh i fermers'kykh hospodarstvakh. Kyiv: BMT (in Russian).

Bencini, R., Pulina, G. (1997). The Quality of Sheep Milk: a review. Australian Journal of Experimental Agriculture. 37, 485-504.

Ayyash, M.M., Sherkat, F., Shah, N.P. (2012). The effect of $\mathrm{NaCl}$ substitution with $\mathrm{KCl}$ on Akawi cheese: Chemical composition, proteolysis, angiotensinconverting enzyme-inhibitory activity, probiotic survival, texture profile, and sensory properties. Journal of Dairy Science. 95(9), 4747-4759. doi:10.3168/jds.2011-4940.

Стаття надійшла до редакиії 15.09.2016 